DOI https://doi.org/10.30525/978-9934-26-146-6-38

\title{
TEACHERS' PROFESSIONAL READINESS TO IMPLEMENT DIGITAL TECHNOLOGIES
}

\author{
Zaitseva I. O. \\ Candidate of Pedagogical Sciences, \\ Assistant Professor at the Department of Foreign Languages \\ Sumy State University \\ Sumy, Ukraine
}

Introduction. Modernization of modern education in Ukraine in the context of European requirements focuses on finding approaches to solving new educational problems. Innovative transformations demand from the teacher a particularly high level of his theoretical knowledge and practical training. The introduction of digital technologies in all spheres of life requires from the specialist information competence, the desire for continuous professional growth, the acquisition of new knowledge in accordance with the demands of the modern labor market, the combination of professional activity with lifelong learning. The development of the infrastructure of educational institutions needs the inclusion of new approaches, methods and technologies in the educational process. One of the most important principles of the implementation of digital technologies in teaching is teachers' professional readiness to organize it. Modern online resources allow you to solve a variety of problems to improve the professional level of teachers. The readiness of the teacher to develop, test and implement pedagogical innovations in the educational process is considered a necessary component of his professional readiness. The teacher's digital competence consists of the following components: media literacy, the ability to effectively use online resources, willingness to cooperate on the Internet. Thus, the formation of foreign language teachers' readiness to use modern educational technologies today is relevant.

Material and Methods. The work of many researchers is devoted to the formation of professional readiness. In a number of studies, the readiness of the teacher is considered along with the concepts of «competence» and «professionalism» (N. Nikandrov, I. Rezanovych, N. Sakharova, etc.). I. Dychkivska, O. Bartkiv, K. Makagon, V. Slastyonin, O. Ogienko and others have been studying the teacher's readiness for innovative activity in recent years. N. Mulina, V. Urusky, O. Vyushkina and others covered in their works the problems of teachers' activity on the application of modern innovative technologies and online resources. Foreign researchers E. Fields, 
K. Goldin, L. Katz and others also pay attention to this problem. Despite the significant results of research in these areas, important aspects of the problem of forming the teachers' professional readiness for the introduction of digital educational technologies remain out of the field of scientists' view.

The purpose of the article is to determine the essence and structure of the teacher's readiness to implement digital technologies; to analyze pedagogical conditions of formation the teacher's readiness for introduction the innovative teaching forms at university.

Results and analysis. Reforming the education system of Ukraine in the information society is characterized by increasing requirements for the formation and development of a new information culture. Computer literacy and information competence of a teacher are important factors in increasing the efficiency and success of pedagogical activities. Thus, these goals and objectives highlighted the need for theoretical justification of some aspects of forming the teachers' professional readiness to implement modern educational technologies in higher education.

I. Dychkivska in her scientific works notes that the structure of readiness for innovative pedagogical activity is considered as a set of motivational, cognitive, creative, reflexive components, which are interdependent and interconnected [2, p. 248]. O. Bartkiv believes that «readiness for innovative pedagogical activity is a special state of personality, which presupposes the teacher's motivational and value attitude to professional activity, possession of effective ways and means to achieve pedagogical goals, ability to creativity and reflection» [1, p. 53]. Professional readiness is a natural result of special training, self-determination, education, self-education and upbringing. This is a mental, active state of personality. Such readiness regulates activity, provides its efficiency. One of the important qualities of a teacher, a condition of his success as a professional is the willingness to innovate, in particular, in the field of foreign language teaching with the using of digital technologies.

The study of scientific papers on the analysis of teachers' readiness allows us to identify the following structural components of this concept:

1. Motivational component determines the motive, purpose, desire of teachers to apply in their professional practice innovative educational technologies.

2. The cognitive component of a teacher's readiness to use digital technologies in the educational process includes knowledge and skills that allow them to use these technologies in their professional activities.

3. The technological component of the teacher's readiness for the successful use of information and communication technologies is a set of practical skills necessary for the implementation of the above mentioned learning technologies in professional activities. 
K. Macagon's model of the structure of the teacher's readiness for innovation contains motivational-orientational, content-operational and diagnostic-reflexive components [4]. Motivational and orientational component is the basis for structuring the basic properties and qualities of the teacher's personality as a professional. The content-operational component includes the ability to creatively rethink innovations in accordance with the conditions of a particular educational institution; the desire to master new information and professional methods and tools. Diagnostic-reflexive component of readiness for innovative activity reflects skills and abilities of the analysis of innovative process, its adjustment, forecasting; ability to anticipate possible needs and problems of innovation.

$\mathrm{O}$. Bartkiv emphasizes that «readiness for innovation is determined by the organization of the optimal innovation environment and the focus of pedagogical activities on innovation». In training teachers for innovative activities, in her opinion, the teacher's interaction with students should meet the following principles: continuity and integrity of personal development, harmonization of pedagogical activities, integration of all its aspects; professional and practical orientation; alternative, freedom of choice; awareness of professional and personal development in pedagogical interaction; creative self-expression, cooperation and co-creation [1, p. 54].

The successful formation of teachers' readiness to use innovative technologies and implement them effectively in pedagogical activities directly depends on the following organizational and pedagogical conditions: helping teachers to overcome psychological barriers to online learning; use of material and technical base, which consists of both hardware and software; organizational and methodological support, including modern educational technologies, methods of networking, criteria for assessing knowledge. Researcher O. Ogienko considers a high level of teachers' readiness for innovative activity as a necessary condition for carrying out innovative activity; creation of an innovative educational environment in the educational institution; using in teaching process the forms, methods and techniques that are aimed at forming an individual style of activity as a result of teachers' readiness for innovative activities; developing of cognitive and professional orientation of students (classes-conference, discussion, business game, etc.) [5].

Conclusions. Having considered the essence, structure, components of teachers' professional readiness for application of digital technologies in teaching, factors and conditions of its formation, it is possible to draw the following conclusions.

1. Formation of teachers' readiness for introduction of digital technologies in teaching is an actual problem of modern science. The readiness of a university teacher to use online learning is a set of professionally significant 
knowledge, skills and abilities, as well as purposeful expression of personality, which includes internal prerequisites for the teacher's activities using innovative technologies in the educational process.

2. Motivational, cognitive and technological components together represent the structure of the teacher's readiness to use innovative educational technologies. This readiness is a personal education, mediates the relationship between the effectiveness of teachers and the focus on improving their professional level. The use of modern online tools provides an opportunity to inflame students, increase their motivation to learn a language independently, overcome the language barrier, develop a positive attitude of students to learning a foreign language.

\section{References:}

1. Bartkiv O. Readiness of the teacher for innovative professional activity. Problemy pidgotovky suchasnogo vchytelya. 2010. № 1. pp. 52-58 [in Ukrainian].

2. Dychkivska I. Innovative pedagogical technologies. K. : Akademvydav, 2015. pp. 253-270 [in Ukrainian].

3. Zaitseva I. Professional readiness of the teacher to use distance technologies. Science and Education a New Dimension. Pedagogy and Psychology : mezhdunar. nauch. zhurnal. III (25), Issue : 49. Budapest, 2015. pp. 25-28 [in Russian].

4. Makagon K. Diagnosis of teachers' readiness for search activities. Ridna shkola. 2002. №1. pp. 27-29 [in Ukrainian].

5. Ogienko O. Formation of readiness for innovative activity as an important component of future teachers' professional training. Pedagogichni nauky: teoria, istoria, innovatsijni tehnologii. 2013. № 7 (33). pp. 154-162 [in Ukrainian].

6. Digital skills and competence, and digital and online learning. European Training Foundation. Turin, 2018. 72 p. [in English]. 